\title{
Herbicide Resistance Management in Florida Tomato Production ${ }^{1}$
}

\author{
Shaun M. Sharpe, Nathan S. Boyd, Ramdas G. Kanissery, and Peter J. Dittmar ${ }^{2}$
}

Herbicide resistance has become a topic of importance to horticultural producers in recent years. This EDIS document provides a definition of herbicide resistance, explains how it develops, and provides management recommendations for tomato growers. It was written for growers and Extension agents, but the information may be of interest to anyone concerned about herbicide resistance in vegetable and small fruit crops.

\section{What is herbicide resistance?}

Herbicide resistance is the inherited ability of a formerly susceptible plant population to survive and reproduce following herbicide exposure at rates that normally kill susceptible plants (Vencill et al. 2012). More simply, resistance is when an herbicide used to work on a particular weed, but no longer does. Resistance may occur due to a variety of reasons, including mutations that inhibit herbicide binding to target sites within the plant, changes in herbicide movement throughout the plant, the ability to metabolize the herbicide to nontoxic chemicals, or a general adaptive stress response (Délye et al. 2013). The resulting resistant population is referred to as the resistant biotype.

Herbicide tolerance describes the historical and current ability of a plant population to survive and reproduce when exposed to a given herbicide dose (Ross and Lembi 2009). Herbicide tolerance refers to a situation where a tolerant plant type was never susceptible to the herbicide. Most agricultural herbicides are selective and kill certain species while others survive (naturally tolerant). For example, Tricor (metribuzin) is applied preemergence to control lambsquarters (Chenopodium album L.), yet it does not harm tomato plants. It is important to differentiate between herbicide tolerance and resistance. It is also important to differentiate between resistance and herbicide failure. Herbicide failure is when an herbicide fails to kill a plant due to extraneous factors such as $\mathrm{pH}$ imbalance, improper mixing, inadequate incorporation, improper rates, plant size, uncalibrated equipment, or environmental conditions.

\section{How does herbicide resistance develop?}

Mutations naturally occur within any plant population. In some cases, mutations make a plant resistant to an herbicide that previously killed it. Larger plant populations have an increased chance of developing resistance because the risk increases with every plant exposed (Diggle et al. 2003). Should a resistant biotype occur, future applications of the same herbicide kill susceptible plants, leaving the resistant biotype to grow and reproduce with minimal competition.

A mechanism of action describes precisely how an herbicide kills on a molecular level. Herbicides that kill plants in the same way are grouped together into a mechanism

1. This document is HS1398, one of a series of the Horticultural Sciences Department, UF/IFAS Extension. Original publication date November 2020. Visit the EDIS website at https://edis.ifas.ufl.edu for the currently supported version of this publication.

2. Shaun M. Sharpe, postdoctoral associate, Horticultural Sciences Department; Nathan S. Boyd, associate professor, Horticultural Sciences Department, UF/IFAS Gulf Coast Research and Education Center; Ramdas G. Kanissery, assistant professor, Horticultural Sciences Department, UF/IFAS Southwest REC; and Peter J. Dittmar, assistant professor, Horticultural Sciences Department; UF/IFAS Extension, Gainesville, FL, 32611.

The Institute of Food and Agricultural Sciences (IFAS) is an Equal Opportunity Institution authorized to provide research, educational information and other services

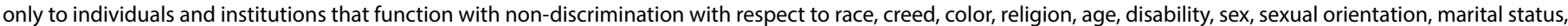

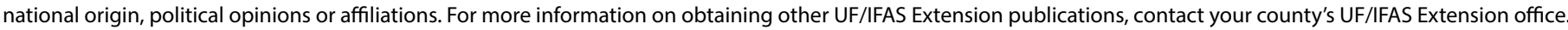
U.S. Department of Agriculture, UF/IFAS Extension Service, University of Florida, IFAS, Florida A \& M University Cooperative Extension Program, and Boards of County Commissioners Cooperating. Nick T. Place, dean for UF/IFAS Extension. 
of action group. Other literature may use the terms "mode of action" or "site of action," but they generally refer to the same concept.

If the same mechanism of action is repeatedly applied, the resistant biotype may spread and dominate a plant population, resulting in complete loss of control. If a plant population develops resistance to one mechanism of action, it is very common for that population to develop resistance to other herbicides with the same mechanism of action, even if that herbicide has never been applied to a given field previously. It is also possible for weeds to become resistant to multiple mechanisms of action. The time frame for resistance to develop varies widely but is influenced by population size, genetic variability, self-pollination, germination percentage, and herbicide rotations (Diggle et al. 2003).

Herbicides differ in the likelihood of causing resistance, the rate at which resistance develops, and the number of species that develop resistance. For example, there are more species resistant to ALS and PSII inhibitors than other mechanisms of action (Figure 1). This is important for tomato growers to consider because halosulfuron (Sandea) is the only postemergence herbicide that can be used for nutsedge control in tomatoes, and it is an ALS inhibitor. This would suggest that there is a reasonable chance that nutsedge plants will develop resistance to halosulfuron after multiple years of use. However, nutsedge species are a perennial plant that rarely reproduces by seed. This means resistance is less likely to occur or will occur over a much longer time period simply because mutations that naturally occur are more prolific through sexual reproduction. Even so, herbicide resistance does evolve in perennial plants, and appropriate measures should be taken to lessen its likelihood.

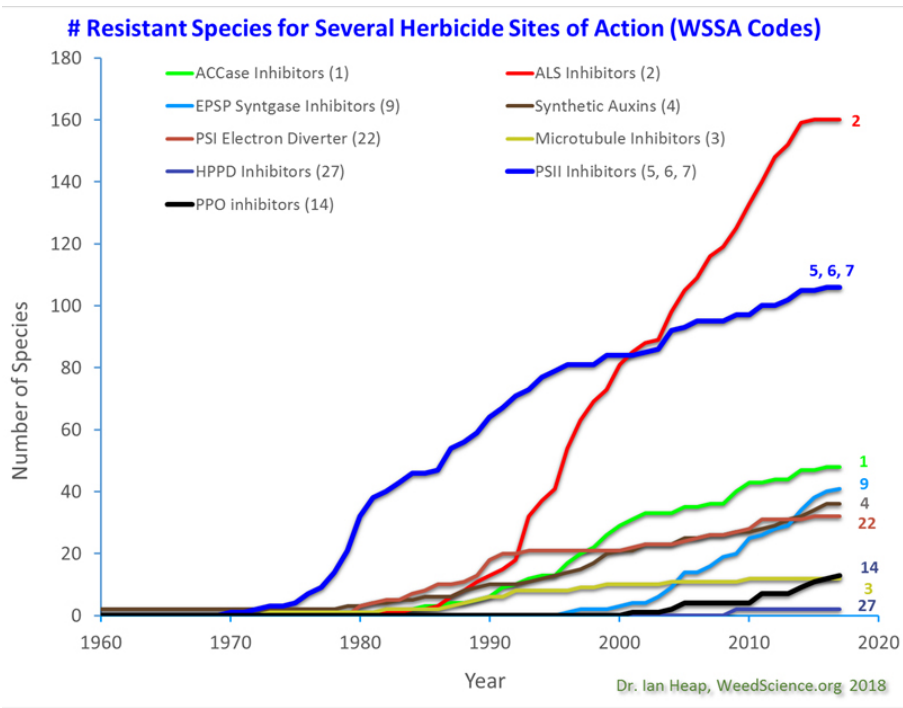

Figure 1. Timeline for cumulative herbicide-related mutations by plant species worldwide.

Credits: Dr. Ian Heap. WeedScience.ora
Vegetables have far fewer herbicide-resistant weeds than many other crops (Figure 2). There are many reasons for this, including (1) the limited use of herbicides in vegetable crops in the past, (2) the overall low acreage of vegetables and thus overall lower population exposure to the herbicide, (3) the use of fumigants and plastic mulches, (4) intensive cultivation, and (5) the use of hand weeding to remove survivors. Resistant weeds most frequently appear when vegetable crops are grown in areas where agronomic crops were grown in the past or where broad-spectrum herbicides are used repeatedly across a range of vegetable crops for pretransplant burndown or crop termination. The development of paraquat resistance in goosegrass (Eleusine indica) (Figure 3) is a good example of the latter phenomenon. The loss of methyl bromide has led to an increased reliance on herbicides in some vegetable crops because most of the registered fumigant alternatives do not adequately control weeds. Thus, the increased rate of development of herbicide resistance within vegetable fields may be an unintended consequence of the phaseout of methyl bromide. Herbicide resistance is likely to occur with increased use, but practices such as hand weeding should inhibit or slow its development.

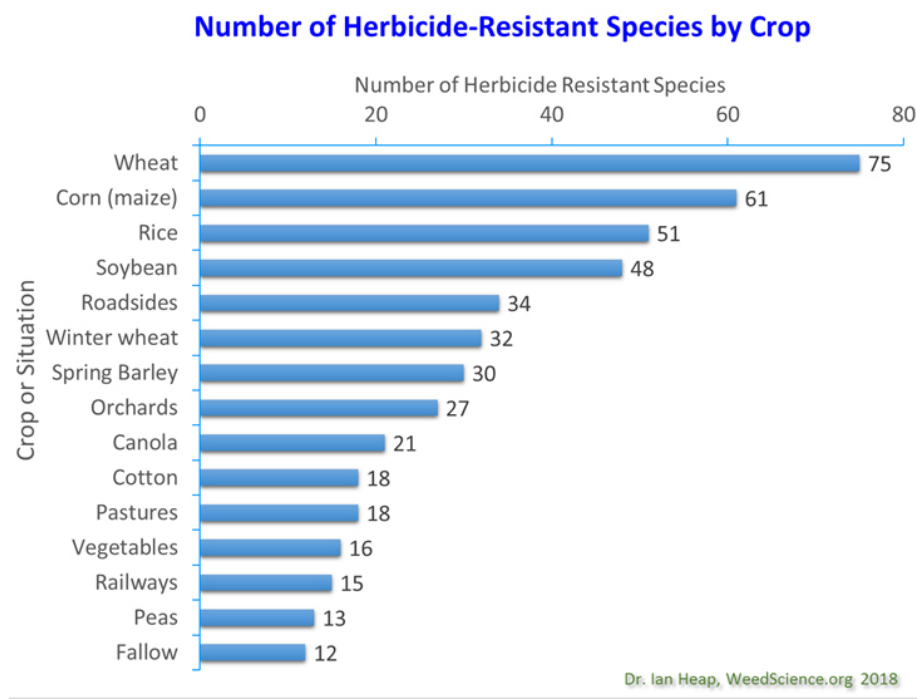

Figure 2. Number of herbicide-resistance accounts per crop or situation.

Credits: Dr. Ian Heap, WeedScience.org

Though herbicide resistance develops slowly in vegetable crops, once it occurs it is likely to spread rapidly and cause serious yield loss. This is because (1) there are a limited number of herbicides registered for use in vegetable crops, making it difficult to find and rotate alternative modes of action, (2) vegetable crops rarely form a competitive canopy, (3) vegetables are very susceptible to competition, and (4) vegetable growers often do not utilize complex crop rotations. Steps should be taken to slow the development 
of herbicide resistance, especially because several resistant weed species already occur in vegetables (Heap 2016). For example, goosegrass, ragweed (Ambrosia artemisiifolia), and wild radish (Raphanus raphanistrum) are all species that commonly occur in vegetable crops and have developed resistance to glyphosate in certain regions of the world. All growers need to take the appropriate steps to reduce the risk of the development of herbicide resistance, because poor management by one individual can have negative consequences for the entire community.

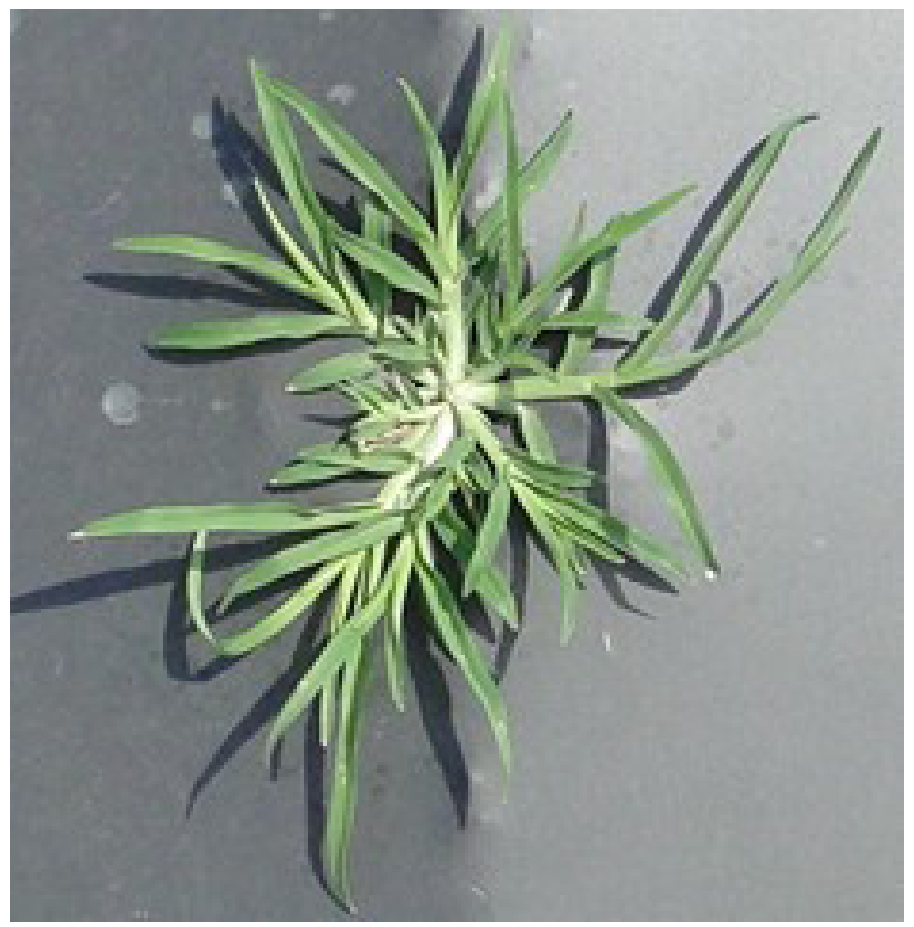

Figure 3. Goosegrass [Eleusine indica (L.) Gaertn.] growing in a plasticmulch-covered bed.

Credits: Shaun M. Sharpe, UF/IFAS

\section{Herbicide-Resistant Weeds in Florida}

Multiple weed species in Florida have documented herbicide resistance. A resistant biotype of goosegrass that demonstrated a 30-fold increase in resistance to paraquat was found in Manatee County (Buker et al. 2002). This goosegrass biotype is a good example of a weed that is widespread in vegetables. Lack of management can result in yield loss, while any efforts to control it will increase the cost of crop production. Group 1 herbicides are a potential management tool for paraquat-resistant goosegrass, but if they are not used in combination with other mechanisms of action, the risk for further resistance development is high.

In addition, a case of group 9 (EPSP Synthase) resistance to glyphosate has developed in ragweed parthenium (Parthenium hysterophorus L.) (Fernandez et al. 2015).
Two paraquat-resistant populations of American black nightshade (Solanum americanum) (Figure 4) were found, one in Collier County demonstrating a 12 -fold increase in tolerance and one in Manatee County demonstrating an 8 -fold increase in tolerance, compared to a sensitive biotype (Bewick et al. 1990). It is possible that other resistant weed species exist but have not yet been identified, because resistance management and monitoring in horticultural crops has typically not received as much attention as row crops or agronomic crops.

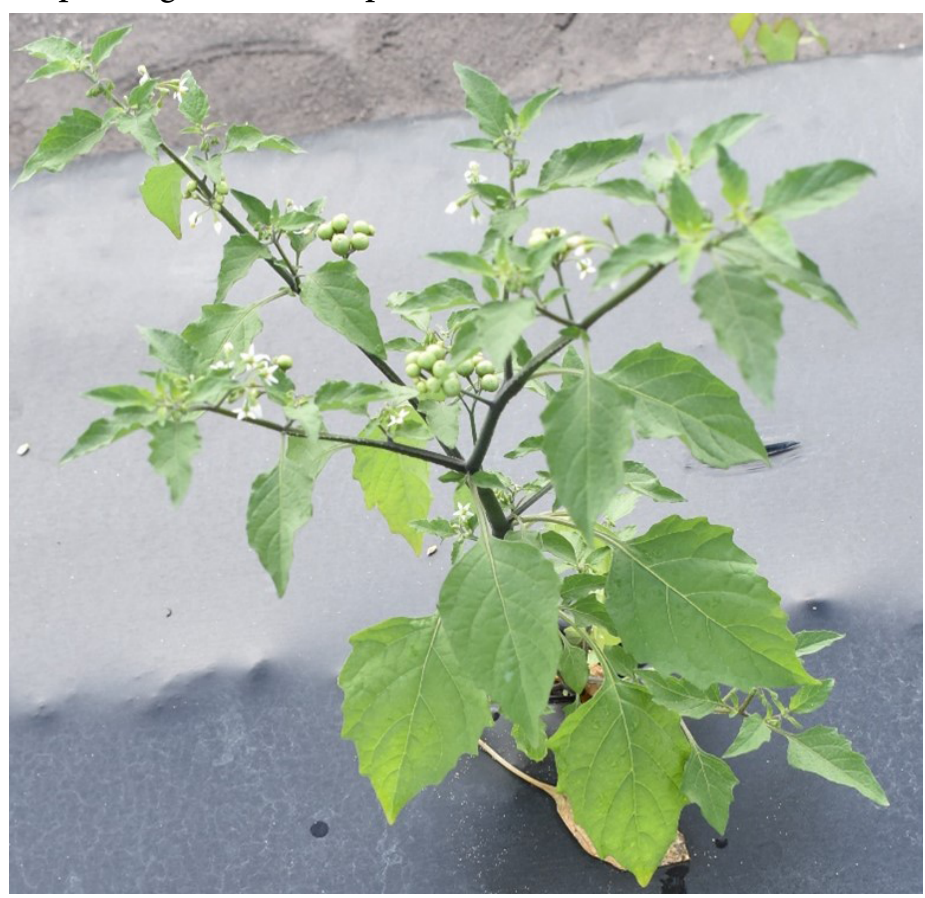

Figure 4. American black nightshade (Solanum americanum Mill.) growing in a plastic-mulch-covered bed. Credits: Shaun M. Sharpe, UF/IFAS

Other weed species are a concern for tomato growers, particularly purple nutsedge. Postemergence control options for purple nutsedge in the tomato bed are limited primarily to Sandea (halosulfuron). Sandea is typically applied repeatedly each growing season and in some cases multiple times in the same year. Herbicide resistance is an issue that has the potential to affect all growers. Careful use of herbicides and the development of integrated pest management programs will at least delay the development of resistance and will reduce long-term weed management costs.

\section{Best Management Practices}

Norsworthy et al. (2012) published a manuscript on the topic of reducing the risk of herbicide resistance. In this paper, the authors list 11 best management practices, which use all aspects of integrated weed management (IWM), including chemical, cultural, and mechanical control options. These recommendations were made generally across 
the majority of cropping systems. Here, we take relevant recommendations and relate them specifically to Florida tomato production.

\section{BMP 1: Scout routinely}

Scouting is the foundation for a strong field-specific IPM program and the first defense against establishment of herbicide-resistant biotypes. Scouting allows growers to monitor and record the presence, location, and abundance of weeds. Record-keeping is critical, especially between years, and will help growers determine when control measures are inadequate. There are two priorities to consider when scouting to reduce the risk of herbicide resistance. The first is to prevent weeds from reproducing (BMP 3). The second is to scout after herbicide applications to identify vegetation that survives applications so that alternative management plans can be developed in a timely manner. Success requires scouting during the time interval when herbicides are expected to have killed plants and before weed seeds are produced. Some recommendations are found in Table 1. For assistance identifying weed species, please contact your local UF/IFAS Extension office.

\section{BMP 2: Understand weed biology}

In addition to scouting, growers should use an understanding of the biology of problematic species in their fields to plan control measures. For example, it is important that growers note which weeds occur in a given season as well as the time between cultivation and weed emergence within each season. This information can help growers select the appropriate herbicide and time preemergence applications to occur prior to emergence. It is also important to note when specific growth stages occur because this impacts herbicide efficacy. Postemergence herbicides should be applied (1) to perennial plants, such as purple nutsedge, when you have 3-4 open leaves but prior to flowering; (2) when grasses have 2-4 leaves or a tuft is less than $10 \mathrm{~cm}$ in diameter; or (3) when broadleaf weeds are 2-4 inches tall (BMP 5). Understanding how a weed grows, be it prostrate or erect, may help understand why an herbicide is ineffective (e.g., crop shielding). Lastly, understanding how long it takes a weed to reproduce may mean control of a weed can be delayed until tillage at the end of the production cycle or fallow period if it does not go to seed (BMP 9). It is recommended that tomato growers focus on what is perceived as the most problematic or widespread weed species, know which products are available for POST control, and apply these products generally at the 2-to-5-leaf stage, or at the latest, before flowering. As a last-ditch effort, hand weeding may be the only alternative.

\section{BMP 3: Use a diversified approach to prevent weed reproduction}

When it comes to resistance development, it's not a matter of if, but when. Every individual plant within a weed population that is exposed to an herbicide may develop resistance. It is not enough to simply focus on killing weeds; the ultimate goal should be to reduce a weed population over time by employing every available tool. This approach will reduce the risk of herbicide resistance by reducing the odds of selecting for a resistant biotype. Limiting the overall population size also provides the added benefit of reducing long-term inputs. Combining this strategy with the use of a diversified list of available tools to control weeds is the central tenet for preserving herbicides in tomato production. Integrated pest management control methods are often grouped by chemical (BMP 4 and 5), cultural (BMP 6 and 8), biological (BMP 7), and physical/mechanical (BMP 7). Many species of weeds may infest a tomato field at any given time, and due to differences in their growth (BMP 2), efficacy of control measures may vary. Therefore, when developing an IPM strategy, it is important to identify the most problematic and persistent weeds and orient management strategies to target those weeds. Tools include herbicides, cover crops, plastic mulches, mechanical cultivation, and hand weeding, which will be covered in more depth below.

\section{BMP 4: Use multiple herbicide mechanisms of action}

Herbicides are the backbone of any conventional IPM strategy for weed management. Should a resistant biotype evolve and control be lost, the herbicide will never again control the weed. New herbicide mechanisms of action registered for vegetables occur very rarely (Figure 5), and the chemical industry cannot be depended upon to solve these issue with new mechanisms of action. To protect herbicides and keep them effective, it is important to use multiple mechanisms of action.

Every herbicide has an action spectrum. To use multiple mechanisms of action, all herbicides must have activity on the target weed. For example, if using paraquat (Gramoxone) and clethodim (Select Max) to control weeds in row middles, the IPM strategy for purple nutsedge control only contains paraquat because clethodim does not kill purple nutsedge. This can be difficult for tomato growers because there are limited herbicides registered for use in tomatoes. However, multiple products are registered for use under plastic, and the rotation of these products can delay the onset of herbicide resistance. The rotation of broad-spectrum 
herbicides such as paraquat (used for preplant burndown or crop termination) with herbicides applied under the plastic mulch can also delay the onset of resistance (Beckie 2007). In addition, the use of herbicides during the fallow period that are not used immediately prior to transplant or during the cropping period can help ensure the rotation of multiple modes of action.

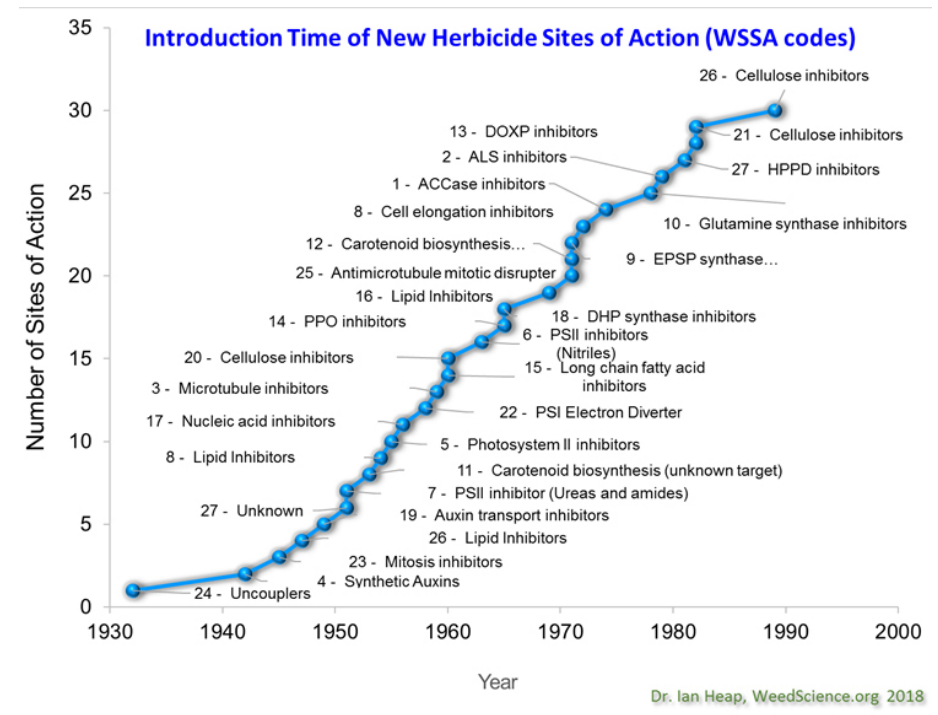

Figure 5. Cumulative timeline for the introduction of new herbicide sites of action.

Credits: Dr. Ian Heap, WeedScience.org

The following will review some important groups of herbicides used in tomato production. Please consult the Vegetable Production Handbook for Florida chapter on tomato production (https://edis.ifas.ufl.edu/cv137) for a more complete listing of herbicides. These groups contain multiple registered herbicides within the same mechanism of action. A summary can be found in Table 2 .

Group 1 (ACCase Inhibitors)-Group 1 contains two registered herbicides, sethoxydim (Poast) and clethodim (Select Max). These are postemergence grass herbicides. This is the only mode of action registered for selective postemergence grass control in tomatoes. To minimize the risk of resistance, growers should also use a preemergent soil-applied herbicide with activity on grasses, such as metribuzin (Tricor) (Group 5) or pendimethalin (Prowl) (Group 3).

Group 2 (ALS Inhibitors)-Many plant species are known to rapidly develop resistance to ALS inhibitors (Figure 1). Herbicides in this group include halosulfuron (Sandea), imazosulfuron (League), and rimsulfuron (Matrix). Halosulfuron (Sandea) is the recommended postemergence herbicide for nutsedge control in tomato, so steps should be taken to slow the development of resistance. In fields where nutsedge occurs, it is recommended that IPM strategies include fumigation with fumigants known to be effective on nutsedge, as well as the use of TIF plastic mulch. Additional measures to preserve the integrity of these herbicides could include limiting their use to in-crop scenarios and relying on alternative modes of action during the fallow period.

Group 5 (Photosynthesis Inhibitors)-Metribuzin is the only Group 5 herbicide registered in tomato. It is included because it is widely used as the backbone weedmanagement tool. It is recommended that this herbicide be rotated with other modes of action with activity on similar species. For preemergence grass control, this may include pendimethalin (Group 3), S-metolachlor (Group 15), or flumioxazin (Chateau) (Group 14). For preemergence broadleaf control, options are similar: $S$-metolachlor (Group 15), flumioxazin (Chateau) (Group 14), or other group 14 herbicides (see below). Please note that some of the listed herbicides can only be used in the row middle and not under the plastic mulch.

Group 14 (PPO Inhibitors)-Group 14 contains some of the most important herbicides used both in the bed and in the row middles. These herbicides are typically applied to the soil and kill weeds after they emerge and are exposed to sunlight. The exception is carfentrazone (Aim), which is typically applied postemergence for broadleaf control in row-middles. Important members of this group include: flumioxazin (Chateau), fomesafen (Reflex), lactofen (Cobra), and carfentrazone (Aim). Care should be taken if tomatoes are being planted behind row crops such as peanuts or cotton, where resistance to these herbicides tends to be common.

Group 22 (Cell Membrane Disrupters/Desiccants)-Group 22 contains only two registered herbicides, but herbicide resistance to each has already evolved in two species. This is likely a consequence of their widespread and continual use as a burndown treatment to control weeds that other control measures have not. Reliance on this group alone in such a role is problematic and should be avoided. Members of this group include diquat (Reglone Desiccant) and paraquat (Gramoxone, Firestorm). Species with documented resistance to paraquat include American black nightshade (Figure 4) and goosegrass (Figure 3). Alternative herbicides to control these weeds include carfentrazone (Aim) for American black nightshade, clethodim (Select) for goosegrass, or glyphosate when possible (preplant burndown, fallow). 


\section{BMP 5: Apply herbicides at labeled rates and to recommended weed sizes}

Always use an herbicide as recommended on the label by applying the recommended rate to the weed at the proper size to maximize effectiveness. Herbicide labels will generally recommend appropriate plant sizes, often when weeds have 2 to 5 leaves. Applying herbicide when weeds are too large is a very common problem, so scouting efforts should focus on identifying weeds when they are very small.

The goal is to get the most control out of the herbicide to avoid the need for sequential applications. Using low herbicide doses has been shown to result in increased survival and allow for the development of resistance in annual ryegrass (Lolium rigidum Gaud.) (Neve and Powles 2005). Several factors may reduce herbicide effectiveness, and they can be broadly grouped into weed- and herbiciderelated issues.

\section{WEED-RELATED ISSUES}

1. Herbicides rarely work on all species. Even broadspectrum herbicides such as glyphosate do not kill all species. Some species are naturally tolerant.

2. As a general rule, weeds are more susceptible when they are small. Larger weeds and weeds that are flowering or have flowered are more difficult to kill. For example, biennial weeds (those that form rosettes and then flower after a period of dormancy) are much more difficult to kill once they flower.

3. Many herbicides (e.g., glyphosate and halosulfuron) work best when weeds are actively growing. Dormant plants or plants stressed due to heat or dry soil conditions may not be adequately controlled by herbicides that are typically effective.

4. Many perennial plants have extensive root systems and underground reproductive organs. A single herbicide application in most cases will not kill all plant organs, enabling the weed to recover. Due to the extensive cultivation practices in tomato production, only purple nutsedge and yellow nutsedge are persistent problems. Both nutsedge species survive tillage by producing tubers, which are perennial storage organs. After cultivation, the tubers will sprout a rhizome, which moves to the surface and gives rise to a corm and a shoot. Over time, nutsedges then will flower and produce additional shoots deriving from the initial shoot. This is very difficult to visualize in the field, particularly under plastic mulch, because a shoot penetrating the plastic may be connected only to a tuber, or it may be interconnected to several shoots. Nutsedges are more susceptible to herbicides when they are smaller, before the shoot produces additional shoots. The best way to time an herbicide application is to monitor fields and apply herbicides after the initial flush of emergence, when shoots contain 3 to 4 leaves, prior to flowering. It is at this time that nutsedges are the most unlikely to have developed subterranean connections and additional shoots, resulting in larger plants.

\section{APPLICATION-RELATED ISSUES}

1. Poor calibration or the use of reduced rates can decrease herbicide efficacy and promote the development of resistance.

2. Use of rates above or below the recommended label rate can reduce efficacy and increase selection for resistance biotypes.

3. Herbicide applications immediately prior to rainfall or during periods of high wind can reduce the amount of herbicide taken up by the plant and reduce overall effectiveness.

4. Poor coverage of the leaf can reduce efficacy, especially with herbicides with low mobility within a plant (e.g., paraquat).

5. Water quality (pH or hardness) can cause herbicides to be broken down within the tank and reduce activity in the plant or limit uptake.

6. Do not leave herbicides stored in spray equipment for extended periods of time. It is best to mix only what you can spray immediately. Many herbicides can be safely tank-mixed, but in some cases, one herbicide will inhibit the activity of another.

7. Improper use of adjuvants or not including a surfactant when recommended can reduce herbicide uptake and efficacy. Hot temperatures may also influence surfactants, particularly crop oils, which may result in severe crop damage.

8. Crop canopy interference or shading by other plants can intercept the herbicide and prevent it from reaching the intended target.

\section{BMP 6: Use cultural practices}

Cultural controls are largely preventative rather than curative. They prevent weeds from emerging and competing 
with the crop by altering some part of the production cycle to make the crop more competitive or to exclude the weeds. Essentially, this puts weeds at a disadvantage.

Plastic Mulches-Plastic mulch is an excellent tool for controlling weeds by removing space and light for weeds emerging in the bed. Plastic mulches are a valuable component of IPM strategies.

- Broadleaf and grass weeds only emerge in the planting holes or row middles.

- Reduce the size of the planting hole to reduce space available for emergence.

- Ensure selected mulch inhibits light penetration, such as black plastic, white on black mulch, or metalized films.

- Purple and yellow nutsedge can pierce the plastic mulch and emerge throughout the bed.

- Totally impermeable film (TIF) can help suppress nutsedge.

Cover Crops-Weeds emerge and thrive in fallow periods. Cover crops are a valuable tool to suppress weed growth, reduce soil erosion, and build up soil organic matter. The use of cover crops, cover crop/herbicide combinations, or multiple herbicide mechanisms of action during the fallow period can help reduce or delay the development of herbicide resistance. Rapidly emerging cover crops that close the canopy quickly are more competitive with weeds, particularly annuals. Cover crops are not effective in controlling nutsedges, and a poorly established cover crop may worsen an infestation.

Planting Dates-Altering planting dates is an important tool available to tomato producers when used in combination with scouting (BMP 1) and resulting historical field records. If a weed species is present in the field, planting dates can be altered to avoid emergence of the weed within the crop. This also permits additional control measures in the fallow, including broad-spectrum, nonselective herbicides. It is acknowledged that growers may be contractually obligated to plant at specific times, but if planting of problem fields could be delayed, this may permit a window for weed emergence prior to the onset of production. An example is wild radish, where cultivation and warmer temperatures may encourage germination. Further cultivation or an herbicide such as glyphosate could be used prior to bed formation.

Optimizing Fertility-Monitoring and adjusting fertility over the season ensures excess and unneeded fertilizer is not available to the weeds. Excessive fertilizer promotes rapid growth and diminishes the time a weed is susceptible to herbicides.

\section{BMP 7: Use mechanical and biological practices when possible}

Tillage-Cultivation can be used during or following fallow periods to kill emerged weeds. This prevents weed species from going to seed. It may also bury seeds that have been deposited on the surface to promote decay, though this is species dependent. Tillage may also be combined with planting date selection (BMP 8) to kill an infestation prior to bed formation.

Hand Weeding-This is among the most ancient control measures for agriculture and the most difficult for weeds to adapt to. It is, unfortunately, labor intensive and expensive. With regard to herbicide resistance risk reduction, it is best employed following scouting (BMP 1) after a postemergence herbicide application to identify and locate weeds that have survived herbicide application. This timing is ideal because it prevents weed reproduction and minimizes competition duration with the crop.

Biological Controls-There are no commercialized, feasible biological agents for controlling weeds in tomato production. Even so, when scouting for insects, proper identification is important to avoid damaging beneficial insects that may feed on weeds and not the tomato crop. Building up population levels of beneficial insects may help suppress weeds, reducing reliance on chemical control measures.

\section{BMP 8: Manage weeds prior to bed formation}

Site selection is an important consideration that determines the starting level of weeds in the field. If possible, a site should be selected with low weed densities and good soil drainage to keep the crop competitive. If possible, chemical (BMP 4 and 5) and physical (BMP 7) methods may be used to reduce infestation levels during fallow periods prior to using the field for tomato production. Fumigation may control some weed species, but it does not provide complete control for all. Risk management for herbicide resistance is not a seasonal strategy but a yearly one. Weed management does not stop when the crop is terminated, and it is critical to be conscious of weed control during and after tomato harvest (BMP 10), during fallow periods, and throughout crop rotations. Every year the goal is to plant into a field with fewer weeds than the year before. 


\section{BMP 9: Prevent both within-field and between-field movement of weed seed or plant parts}

Farm equipment that moves through the field has the potential to move seed within the field and between fields. Cleaning farm equipment between fields can remove seed and prevent infestations from spreading between fields. Routine observation can identify and target high-impact areas (cultivator blades, fronts of tractors) specifically to reduce time investments. If accumulation occurs to the detriment of production (for example, removing plastic), move to the field edge to remove the accumulated biomass. Deposits in the field may produce a new weed patch, and additional options are available for weed control outside the immediate production area.

\section{BMP 10: Manage weed seed at or after harvest to prevent accumulation}

Late-season emerging weeds, either in the row middle, in competition with the tomato plants, or growing alone where the crop may have failed, have a risk of developing herbicide resistance. These weeds were likely not exposed to preemergence herbicides, so the only herbicides they may experience will be during crop termination. Therefore, it is advisable to use a tank-mix of broad-spectrum herbicides, or if that cannot be done, to rotate herbicide modes of action between years (BMP 4). It is also advisable to scout your fields prior to harvest (BMP 1) or at least monitor during harvest to determine weed sizes. This will help determine if the weed is susceptible (BMP 2) and if you can coordinate spray timings. Scouting should occur postapplication to determine if further control measures are required. Should weeds survive, control recommendations depend on their growth stage. If weeds are flowering and developing seeds, it is advisable to use hand weeding (BMP 9) and to remove weed seed from the field. Otherwise, retreat with another mechanism of action. Tillage is a viable option if the fields will be cultivated or tilled under before the weeds form seeds.

\section{BMP 11: Manage field borders to prevent weeds from invading}

Field edges are prime places for weeds to thrive. There are generally fewer disturbances (lower herbicide inputs, little traffic compared to in the field, infrequent cultivation), yet weeds emerging in this area are near water and nutrients. It is inadvisable to completely eradicate all plants along the field edge, from both a cost and environmental perspective. It is important to know from scouting which weeds are problematic in your fields (BMP 1) and ensure they are not reproducing on the field edges. Tillage, mowing, or chemical options are ideal to prevent the production of weed seed.

\section{Detection and Response to Resistance}

If herbicide resistance is suspected, please contact your county UF/IFAS Extension agent as soon as possible for guidance. General recommendations include:

- Re-treat the area with a different mechanism of action if possible.

- Use cultivators or hand weeding to remove the suspected resistant weeds.

- If necessary, destroy the localized area of the field where the resistant weeds occur.

- Rotate herbicide products and crops in subsequent years.

A rapid response to suspected herbicide resistance and efforts to remove the weed before it becomes a widespread problem can significantly reduce long-term management costs. There are several indicators that suggest the advent of herbicide resistance:

- Good weed control is observed in most of the field except localized areas. If overall poor control is observed, it is very unlikely to be resistance.

- A species that used to be controlled by a particular herbicide is no longer controlled, and the number of plants of that particular species is increasing from year to year.

- The uncontrolled species appears in a localized patch that spreads from year to year.

- Dead plants of the same species are intermixed with plants that survived the herbicide application.

- Resistance can only be confirmed by studies that examine the susceptibility of a particular weed species to a range of herbicide rates. This type of research takes time but can be conducted by many weed scientists at the University of Florida.

\section{References}

Beckie, H. J. 2007. "Beneficial Management Practices to Combat Herbicide-Resistant Grass Weeds in the Northern Great Plains." Weed Technol 21:290-299. 
Bewick, T. A., S. R. Kostewicz, W. M. Stall, D. G. Shilling, K. Smith, W. Science, and N. Nov. 1990. "Interaction of Cupric Hydroxide, Paraquat, and Biotype of American Black Nightshade (Solanum americanum)." Weed Sci 38:634-638.

Buker, R. S., S. T. Steed, and W. M. Stall. 2002. "Confirmation and Control of a Paraquat-Tolerant Goosegrass (Eleusine indica) Biotype." Weed Technol 16:309-313.

Délye, C., M. Jasieniuk, and V. Le Corre. 2013. "Deciphering the Evolution of Herbicide Resistance in Weeds." Trends Genet 29:649-658.

Diggle, A. J., P. B. Neve, and F. P. Smith. 2003. "Herbicides Used in Combination Can Reduce the Probability of Herbicide Resistance in Finite Weed Populations." Weed Res 43:371-382.

Fernandez, J. V., D. C. Odero, G. E. MacDonald, J. Ferrell, and L. Gettys. 2015. "Confirmation, Characterization, and Management of Glyphosate-Resistant Ragweed Parthenium (Parthenium hysterophorus L.) in the Everglades Agricultural Area of South Florida." Weed Technol 29:233-242.

Freeman, J. H., E. J. McAvoy, N. S. Boyd, R. Kanissery, H. A. Smith, J. Desaeger, G. E. Vallad and P. B. Williams. 2020. “Tomato Production." In Vegetable Production Handbook of Florida 2020-2021 Edition, edited by P. J. Dittmar, J. H. Freeman, M. L. Paret, and H. A. Smith. 393-443. Gainesville: University of Florida Institute of Food and Agricultural Sciences. https://edis.ifas.ufl.edu/cv137

Heap, I. 2016. “The International Herbicide-Resistant Weed Database." http://www.weedscience.org/. Accessed June 18, 2018.

Neve, P., and S. Powles. 2005. "High Survival Frequencies at Low Herbicide Use Rates in Populations of Lolium rigidum Result in Rapid Evolution of Herbicide Resistance." Heredity (Edinb) 95:485-492.

Norsworthy, J. K., S. M. Ward, D. R. Shaw, R. S. Llewellyn, R. L. Nichols, T. M. Webster, K. W. Bradley, et al. 2012. "Reducing the Risks of Herbicide Resistance: Best Management Practices and Recommendations." Weed Sci 60:31-62.

Ross, M., and C. Lembi. 2009. Applied Weed Science. 3rd ed. Upper Saddle River, NJ: Pearson Education, Inc. 209-225.
Vencill, W. K., R. L. Nichols, T. M. Webster, J. K. Soteres, C. Mallory-Smith, N. R. Burgos, W. G. Johnson, and M. R. McClelland. 2012. "Herbicide Resistance: Toward an Understanding of Resistance Development and the Impact of Herbicide-Resistant Crops.” Weed Sci 60:2-30. 
Table 1. Scouting recommendations after herbicide applications with considerations to timing in the production cycle. Herbicides listed are only examples and not an exhaustive list. Consult labels for application rates and use patterns.

\begin{tabular}{|l|l|l|}
\hline \multicolumn{1}{|c|}{ Production cycle timing } & \multicolumn{1}{c|}{ Example herbicides } \\
\hline $\begin{array}{l}\text { In-bed-preemergence herbicides applied under } \\
\text { the plastic mulch }\end{array}$ & $\begin{array}{l}\text { Metribuzin, S-metolachlor, flumioxazin, } \\
\text { pendimethalin }\end{array}$ & W to 6 weeks after transplant \\
\hline Row middles-Preemergence herbicides & Flumioxazin, pendimethalin & 4 weeks after treatment \\
\hline Row middles_Postemergence herbicides & $\begin{array}{l}\text { Roundup (glyphosate), Aim (carfentrazone), } \\
\text { Scythe (pelargonic acid) }\end{array}$ & 3 weeks after treatment \\
\hline Posttransplant-Postemergence grass control & Select (clethodim), Poast (sethoxydim) & 3 weeks after treatment \\
\hline Posttransplant-Postemergence nutsedge control & Sandea (halosulfuron) & 4 weeks after treatment \\
\hline Crop termination & Paraquat, diquat & 3 weeks after treatment \\
\hline Fallow & $\begin{array}{l}\text { Postemergence herbicides } \\
\text { Preemergence herbicides }\end{array}$ & $\begin{array}{l}3 \text { weeks after treatment } \\
4 \text { to } 6 \text { weeks after treatment }\end{array}$ \\
\hline
\end{tabular}

Table 2. Summary of important Florida tomato production herbicide categories, typical weed spectrum, use patterns, and symptomology.

\begin{tabular}{|c|c|c|c|c|c|c|}
\hline Herbicide group & $\begin{array}{l}\text { Group } \\
\text { number }\end{array}$ & Herbicides & $\begin{array}{l}\text { Typical target } \\
\text { weed spectrum }\end{array}$ & $\begin{array}{l}\text { Typical use } \\
\text { pattern }\end{array}$ & Symptomology & Time frame \\
\hline $\begin{array}{l}\text { Acetyl CoA } \\
\text { Carboxylase } \\
\text { (ACCase) Inhibitors }\end{array}$ & 1 & $\begin{array}{l}\text { Clethodim } \\
\text { (Select), } \\
\text { sethoxydim } \\
\text { (Poast) }\end{array}$ & $\begin{array}{l}\text { Postemergence } \\
\text { grass control }\end{array}$ & $\begin{array}{l}\text { Bed-top and } \\
\text { row middles }\end{array}$ & $\begin{array}{l}\text { New growth will be } \\
\text { chlorotic (yellow) } \\
\text { to necrotic (brown/ } \\
\text { black) }\end{array}$ & $\begin{array}{l}\text { Growth cessation will be } \\
\text { quick (within a few days), } \\
\text { death } 1 \text { to } 2 \text { weeks. }\end{array}$ \\
\hline $\begin{array}{l}\text { Acetolactate } \\
\text { Synthase (ALS) } \\
\text { Inhibitors }\end{array}$ & 2 & $\begin{array}{l}\text { Halosulfuron } \\
\text { (Sandea), } \\
\text { imazosulfuron } \\
\text { (League), and } \\
\text { rimsulfuron } \\
\text { (Matrix) }\end{array}$ & $\begin{array}{l}\text { Postemergence } \\
\text { nutsedge control }\end{array}$ & $\begin{array}{l}\text { Post-directed } \\
\text { on bed-top, row } \\
\text { middles. }\end{array}$ & $\begin{array}{l}\text { Interveinal chlorosis, } \\
\text { leaf purpling, } \\
\text { leaf distortion/ } \\
\text { malformation, } \\
\text { overall chlorosis, } \\
\text { necrosis }\end{array}$ & $\begin{array}{l}\text { Slow }-2 \text { to } 3 \text { weeks to show } \\
\text { symptoms }\end{array}$ \\
\hline Mitosis Inhibitors & 3 & $\begin{array}{l}\text { Pendimethalin } \\
\text { (Prowl) }\end{array}$ & $\begin{array}{l}\text { Grasses, some } \\
\text { broadleaves }\end{array}$ & $\begin{array}{l}\text { Preemergence } \\
\text { control, applied } \\
\text { to the bed-top } \\
\text { or row middles. }\end{array}$ & $\begin{array}{l}\text { General emergence. } \\
\text { Root malformation } \\
\text { and stunting, } \\
\text { aboveground } \\
\text { stunting, leaf } \\
\text { malformations. }\end{array}$ & $\begin{array}{l}\text { Weeds typically will not } \\
\text { emerge. }\end{array}$ \\
\hline $\begin{array}{l}\text { Photosystem II } \\
\text { Inhibitors (PSII) }\end{array}$ & 5 & $\begin{array}{l}\text { Metribuzin } \\
\text { (Tricor) }\end{array}$ & $\begin{array}{l}\text { Preemergence } \\
\text { broadleaf and } \\
\text { grass control }\end{array}$ & $\begin{array}{l}\text { Pretransplant } \\
\text { for } \\
\text { preemergence } \\
\text { control in bed; } \\
\text { postemergence } \\
\text { for small weeds }\end{array}$ & $\begin{array}{l}\text { Interveinal chlorosis, } \\
\text { leaf margin necrosis, } \\
\text { leaf malformations. } \\
\text { If used PRE, may } \\
\text { show symptoms on } \\
\text { old growth first. }\end{array}$ & $\begin{array}{l}\text { When used preemergence, } \\
\text { weeds typically will } \\
\text { die shortly following } \\
\text { emergence. }\end{array}$ \\
\hline $\begin{array}{l}\text { Enolpyruvyl } \\
\text { Shikimate-3- } \\
\text { Phosphate (EPSP) } \\
\text { Synthase Inhibitors }\end{array}$ & 9 & $\begin{array}{l}\text { Glyphosate } \\
\text { (Roundup) }\end{array}$ & $\begin{array}{l}\text { Nonselective, } \\
\text { broad-spectrum. }\end{array}$ & $\begin{array}{l}\text { Preplant } \\
\text { burndown }\end{array}$ & $\begin{array}{l}\text { Leaf malformations, } \\
\text { chlorosis, stunting }\end{array}$ & $\begin{array}{l}\text { Slow acting; may take } 2 \text { to } 3 \\
\text { weeks to see necrosis. }\end{array}$ \\
\hline $\begin{array}{l}\text { Protoporphyrinogen } \\
\text { Oxidase Inhibitors } \\
\text { (PPO or Protox) }\end{array}$ & 14 & $\begin{array}{l}\text { Flumioxazin } \\
\text { (Chateau), } \\
\text { fomesafen } \\
\text { (Reflex), } \\
\text { carfentrazone } \\
\text { (Aim), lactofen } \\
\text { (Cobra) }\end{array}$ & $\begin{array}{l}\text { Preemergence } \\
\text { broadleaf control }\end{array}$ & $\begin{array}{l}\text { Pretransplant } \\
\text { on bed-top. }\end{array}$ & $\begin{array}{l}\text { Necrotic spots, leaf } \\
\text { malformations, } \\
\text { chlorosis. May } \\
\text { present in older } \\
\text { growth first. }\end{array}$ & $\begin{array}{l}\text { When used preemergence, } \\
\text { weeds typically die shortly } \\
\text { following emergence. When } \\
\text { used postemergence, rapid } \\
\text { chlorosis and necrosis of } \\
\text { exposed leaves. }\end{array}$ \\
\hline $\begin{array}{l}\text { Photosystem } \\
\text { I Inhibitors } \\
\text { (Desiccants) }\end{array}$ & 22 & $\begin{array}{l}\text { Paraquat, } \\
\text { diquat }\end{array}$ & $\begin{array}{l}\text { Broad-spectrum, } \\
\text { nonselective, } \\
\text { postemergence } \\
\text { control }\end{array}$ & $\begin{array}{l}\text { Row middles, } \\
\text { crop } \\
\text { termination }\end{array}$ & $\begin{array}{l}\text { Initially leaves } \\
\text { will appear water- } \\
\text { soaked, then } \\
\text { chlorotic (yellow) } \\
\text { and necrotic } \\
\text { (brown/black) }\end{array}$ & $\begin{array}{l}\text { Rapid-necrosis may show } \\
\text { as early as } 3 \text { days. }\end{array}$ \\
\hline
\end{tabular}


Table 3. Example management programs for select weed species within Florida tomato production.

\begin{tabular}{|c|c|c|c|}
\hline Stage & Purple nutsedge & Goosegrass & American black nightshade \\
\hline Fallow & Glyphosate and tillage & Glyphosate, EPTC & Glyphosate, timely mowing or cultivation. \\
\hline Preplant Burndown & $\begin{array}{l}\text { Paraquat or glyphosate (rinse } \\
\text { plastic mulch afterward). }\end{array}$ & $\begin{array}{l}\text { Paraquat, glyphosate (rinse } \\
\text { plastic mulch afterward), } \\
\text { pelargonic acid }\end{array}$ & $\begin{array}{l}\text { Pyraflufen, glyphosate (rinse plastic } \\
\text { afterward), pelargonic acid }\end{array}$ \\
\hline $\begin{array}{l}\text { Preemergence-In the } \\
\text { bed }\end{array}$ & $\begin{array}{l}\text { Fomesafen, S-metolachlor, EPTC } \\
\text { may provide suppression. }\end{array}$ & Napropamide, S-metolachlor & Oxyfluorfen \\
\hline $\begin{array}{l}\text { Postemergenece-In the } \\
\text { bed }\end{array}$ & Halosulfuron & Clethodim, sethoxydim & $\begin{array}{l}\text { No chemical options available. Only hand } \\
\text { weeding. }\end{array}$ \\
\hline $\begin{array}{l}\text { Preemergence-Row } \\
\text { middles }\end{array}$ & $\begin{array}{l}\text { Fomesafen, S-metolachlor, or } \\
\text { EPTC may provide suppression. }\end{array}$ & $\begin{array}{l}\text { Pendimethalin, flumioxazin, } \\
\text { DCPA }\end{array}$ & Flumioxazin \\
\hline $\begin{array}{l}\text { Postemergence-Row } \\
\text { middles }\end{array}$ & Halosulfuron & $\begin{array}{l}\text { Clethodim, sethoxydim, } \\
\text { paraquat }\end{array}$ & Carfentrazone, lactofen, paraquat \\
\hline Crop termination & Vapam HL or KPam HL & Vapam HL or KPam HL & Vapam HL or KPam HL \\
\hline
\end{tabular}

